\title{
The affirmative action chess game at UFRJ
}

Marcelo Paixão ${ }^{1}$

Irene Rossetto ${ }^{2}$

In this paper, we discuss the process that led the Federal University of Rio de Janeiro (UFRJ) to adopt affirmative action admissions measures in the early 2010s. Over the past two decades, scholarly interest has increased attention to these public policies in Brazil. Gaspar and Barbosa (2013) compiled 464 studies, which collectively researched affirmative action cases in Brazil between 1999 and 2012. The majority of research about affirmative action has focused on normative arguments based on principles of social justice and collective identities formation - or, in this case, Afro-Brazilian identity and its intersections of gender, youth and territory. Fewer empirical studies have researched the institutional decision-making processes during the implementation of affirmative action policies in Brazil's universities. This gap has led to surprisingly little discussion about the internal process of adoption of affirmative action measures. It is true that some authors have been interested in targeted questions concerning the narrative of the adoption (or at least the first steps toward the adoption) of affirmative action measures in the vestibular ${ }^{3}$ exams. In this regard, the most significant contribution was the book edited by Jocélio Santos (2012), which examined the controversies that occurred in 11 University Councils of public higher education institutions all over Brazil and emphasized the main social agents who favored or opposed affirmative action policies. Other research analyses were narrowly concerned with the socioeconomic profile of undergraduate students (Santos 2013; Gomes and Martins 2004; Lopes and Braga 2007). Using quantitative or qualitative methods, these studies compared demographic diversity before and after the inclusion of affirmative action policies. They also pointed out the institutional problems of dealing with an unprecedentedly diverse student body and the difficulties of promoting student body retention, mainly due to lack of adequate support for low-income, black and brown students ${ }^{4}$ who had entered university through affirmative action programs.

Much less is known about the internal institutional debate prior to and leading to the approval of the adoption of affirmative action measures. In 2012, a national law was passed requiring all Brazilian federal higher education institutions to implement quotas on the basis of attendance at public high school, family income, and racialethnic criteria. The aim of this paper is to explore the process by which UFRJ adopted

\footnotetext{
${ }^{1}$ Associate Professor, The University of Texas at Austin.

${ }^{2}$ Research Associate, The University of Texas at Austin.

${ }^{3}$ The term "vestibular" is used in Brazil to refer to the undergraduate admission selection process.

${ }^{4}$ In this paper, we use Brazil's official census categories "black" (preto) and "brown" (pardo) to refer to AfroBrazilian students who benefit from race-based affirmative action policies.
} 
an affirmative action policy between 2010 and 2012. Drawing on the positions of the social players involved in the decision-making process, we highlight the pivotal role of the President of UFRJ. The study takes a novel approach by discussing internal institutional politics in one particular university and contributing to understanding of the role of the agents inside the academic community in shaping affirmative action policies.

The choice to examine UFRJ's case was driven by the importance of this academic institution in Brazil and its position as national bastion against the adoption of affirmative action. This university is the third-largest public institution of higher education in Brazil-both in terms of number of undergraduate students (about 36 thousand active enrolled students in 2016), and number (139) of undergraduate courses. ${ }^{5}$ With respect to academic prestige, UFRJ is also one of the most prominent, established universities in Brazil and Latin America. In 2017, a ranking made by the Brazilian newspaper Folha de São Paulo (perhaps the most influential daily paper in the country) recognized UFRJ as the best Brazilian university. ${ }^{6}$ The QS World University Ranking singled out UFRJ as the tenth-best Latin American university (and 331st all over the world $)^{7}$ in 2017. According to the Coordination for the Improvement of Higher Level Personnel (CAPES), ${ }^{8} 20.7 \%$ of the 94 graduate programs were good or excellent (score 6 or 7) in 2017, confirming UFRJ as the second-best university in Brazil in terms of quality and quantity of graduate programs after the University of Sao Paulo (USP). ${ }^{9}$

Yet, UFRJ waited longer than other Brazilian public universities to adopt affirmative action in the admission process. Machado and Silva (2010) showed that between 2002 and 2009, 65 out of 94 Brazilian public institutions of higher education implemented some type of affirmative action programs. ${ }^{10}$ The list included prestigious universities like the University of Brasília, which reserved in $200320 \%$ of its places for black and brown candidates - plus a $10 \%$ bonus score in the admission exam for students of some public schools (Carvalho 2005; Heringer and Ferreira 2009; Machado and Silva 2010). Similarly, in 2004, the University of Bahia embraced a system of social quotas $(40 \%)$ in which a race-based criterion was partially considered (Carvalho 2005; Heringer and Ferreira 2009; Machado and Silva 2010). The University of São Paulo

\footnotetext{
${ }^{5}$ https://ufrj.br/cursos.

${ }^{6} \mathrm{http}: / /$ ruf.folha.uol.com.br/2017/

${ }^{7} \mathrm{https}$ //www.topuniversities.com/university-rankings/world-university-rankings/2018.

${ }^{8}$ CAPES is a Foundation within the Ministry of Education in Brazil whose central purpose is to coordinate efforts to improve the quality of Brazil's faculty and staff in higher education through grant programs (https://www.iie.org/Programs/CAPES).

${ }^{9}$ _USP has 60 graduate programs, 50 of which obtained score 5 or 6 . http://www.capes.gov.br/sala-deimprensa/noticias/8557-divulgado-o-resultado-da-1-etapa-da-avaliacao-quadrienal-2017.

${ }^{10}$ In the case of 48 universities, affirmative action measures had been adopted by internal decision of the University Council. Generally, the adoption of affirmative action programs by State Universities was preceded by a law of the Chambers of State Representatives. For a detailed explanation of the different mechanisms, see Heringer and Ferreira (2009); Machado and Silva (2010); Machado (2013).
} 
adopted a 3\% bonus score in the vestibular system in 2006 (Carvalho 2005; Heringer and Ferreira 2009; Machado and Silva 2010). In contrast, in the 2000s, UFRJ President and key faculty members were against affirmative action. Across Brazil, UFRJ was considered one of the most important universities standing against affirmative action. Because the UFRJ community not only delayed but also openly rejected affirmative action policies, the question that arises is: why did UFRJ finally decide to adopt affirmative action in spite of such strong resistance of its body? To answer to that question, we utilize a combination of resources, like newspaper articles, UFRJ documents, and quantitative data, as well as autobiographical memory - as one of the authors of this paper was directly engaged in the URFJ's debate on affirmative action as a member of the University Council. The first section will contextualize the adoption of affirmative action at UFRJ within the broader national climate. The second will describe the national higher education policy under President Lula. The paper thus considers both the opponents and supporters of affirmative action at UFRJ. Finally, it provides an analysis of the process of adopting affirmative action measures along with the causes leading to their implementation.

\section{Affirmative Action in Brazilian Higher Education: a brief history}

Public universities are generally the highest-ranked institutions in Brazil, offering quality academics along with tuition-free undergraduate and graduate programs. For example, $14 \%$ of the graduate programs of Brazilian public universities were evaluated as excellent (receiving a CAPES's score of 6 or 7), whereas only $6 \%$ of the private universities obtained the same rate (IPEA 2015). On the other hand, admission in public institutions has traditionally been highly competitive, especially considering the restrictive offer of vacancies. Upper and middle-class students, who previously attended private schools and/or expensive preparatory courses, are more likely to pass the vestibular exam than students served by low-quality public primary schools. Telling evidence of these disparities is embodied by school infrastructure. According to Paixão et al. (2010), 34\% of Brazilian students in eight grade ${ }^{11}$ had good or excellent facilities in 2005, whereas $92.4 \%$ of private eighth-grade students reported the same conditions. Moraes and Beluzzo (2014) calculated that, in 2005, the average eighthgrade mathematics score of students from private secondary schools was about $23 \%$ higher than the score of students in public school. It is also worthy of note that, in the late 2000 s, $85 \%$ of all elementary education students were enrolled in public schools,

\footnotetext{
${ }^{11}$ In 2006, Brazil passed an educational reform extending the length of primary education by one year. The official entry age was lowered from seven to six years old. In the new system, the eighth grade and the ninth year correspond to the same year of schooling.
} 
whereas less than $25 \%$ of the secondary education students attended public institutions. When considering the race/color ${ }^{12}$ of the students, we observe that less than $8 \%$ of black and brown elementary education students were enrolled in private schools. By contrast, 18\% of white students attended private schools (Paixão et al. 2010). Extensive research has highlighted the importance of cumulative disadvantages of race and class to explain racial inequality in educational attainment in Brazil (Hasenbalg and Valle Silva 1990; Cavalleiro 2000; Telles 2004; Paixão 2009; Viáfara López and Alvarado 2015; Hordge-Freeman 2015; Marteleto and Dondero 2016). These studies confirm the association between educational performance, position in the social pyramid, and the conditions of public schools, as well as racial discrimination present in the educational system, the society as a whole, and race-based differential treatment within families. A large and growing body of literature concerning higher education and income inequalities also stresses how educational attainment affects salary and career opportunities (Henriques 2000). A study conducted by the Brazilian National Statistical Office (Instituto Brasileiro de Geografia e Estatística - IBGE) revealed that individuals with higher education earned three times more than those with a secondary education degree (IBGE 2016). Higher education also impacts access to political power; in the 53 $3^{\text {rd }}$ Legislature of Brazil's National Congress (2007-2010), 80\% of the 513 deputies had a higher education degree (Paixão and Carvano 2008). Taken together, these studies support the notion that higher education has a crucial role in preserving inequality or impacting upward social mobility. These studies also indicate the importance of factors like race and class in shaping educational mobility opportunities.

Since the 1990s, Brazil expanded the higher education system, adding more than 2.5 million vacancies in the undergraduate courses between 1995 and 2006. This partially reduced racial inequality in higher education. In the late 1990s, less than $2 \%$ of black and brown young people between 18 and 25 were attending college. Ten years later, almost 10\% were enrolled in a degree program at a university (Paixão et al. 2010).

In that period, the proportion of blacks and browns increased at almost twice the rate of whites. However, the expansion of enrollment rates among blacks and browns did not determine a fundamental shift in racial disparities. The least prestigious private institutions were the main access point for black and brown students to higher education. Between 2002 and 2006, the number of black and brown students in public universities increased $31.4 \%$ whereas it expanded $124.5 \%$ in private universities. During the same period, the growth rate of white students in public higher education institutions was $17.4 \%$ whereas it was $31.1 \%$ in private universities (Paixão and Carvano 2008). Some scholars underlined racial disparities as the trigger

\footnotetext{
12 At the present time, Brazil's official statistics ask "which is the race or color" of the respondants. Individuals self identify within the categories: branco (white), pardo (brown), preto (black), amarelo (yellow or Asian), and indígena (indigenous).
} 
for the adoption of affirmative action policies in Brazilian universities (Santos and Lobato 2003; Carvalho 2005). Regardless of underlying motivations, the path to adoption of these policies was not linear. Influential members of civil society, the mass media, and the academic community used Brazilian mixture and the apparent racial harmony to delegitimize public policies based on race. According to Fry et al. (2007), the inevitable result of affirmative action for Afro-Brazilians would be the racialization of the national society and the emergence of racist movements and racial conflict. Experiments proving genetic mixture of famous figures were also used as a finding to invalidate the use of race in public policies (Kent and Wade 2015, Wade 2017). In spite of a vast array of demographic and sociological studies revealing racial inequalities in every aspect of Brazilian society, the idea of racial democracy - even if just as a myth - appeared to be robust enough to negate the use of race to shape public policy. As such, in many cases it was more acceptable to support class-based positive discrimination rather than race-based measures. ${ }^{13}$

Although quotas may sound controversial to many now, they are not a novelty in Brazilian history. In the 1930s, President Vargas issued Decree 19.482, known as Lei dos 2/3 (law of the two-thirds), to address the high unemployment rate and the copious displacement of people from rural to urban centers. Accordingly, all agencies, companies or associations were required to have at least two-thirds of Brazilian-born individuals among their employees. It seems, therefore, that rejection against positive discrimination in Brazilian society arose when proposed in favor of Afro-Brazilians as a collective group. In the 1980s, after the end of the military dictatorship, the renaissance of the black movement was strongly based on the defense of cultural and human rights (Guimarães 2013), while in the 1990s the black movement started to debate affirmative action for blacks and browns in the public arena. During President Fernando Henrique Cardoso's (FHC) mandate (1995-2002), the Government made a formal commitment to address discrimination, creating in 1995 an Inter-Ministerial Working Group to Valorize the Black Population (Grupo de Trabalho Interministerial, GTI) that advocated the discussion on affirmative actions. Several initiatives contributed to advance the idea that Brazil's state had shifted towards the recognition and fight against racial discrimination (Htun 2004). In 1996, for example, an international seminar in Brasília explored race relations and affirmative action in Brazil and the United States. At the same time, despite some early disagreements, black movement organizations started to converge upon the mobilization for affirmative action policies (Heringer 2001; Benedito 2007). According to several authors, the 2001 World Conference against Racism (WCAR), held in Durban, South Africa, rendered

\footnotetext{
${ }^{13}$ A study conducted by Bailey et al. (2015), using data from LAPOP's Americas Barometer, found out that Brazilian population mostly supported race-based affirmative actions, especially when conditioned to class-based quotas. They also observed that lower levels of education and income were greater associated with support for race-based quotas.
} 
new national commitments to the recognition of national diversity and to the fight against forms of ethnic-racial discrimination. Several studies suggested that the preparatory activities held by local and federal governments, the black movement and scholars, the debate in the media and the conference itself were decisive to the pursuit of affirmative actions in Brazil (Htun 2004; Telles 2004; Schwartzman and Paiva 2016). Not coincidently, in 2002, the State of Rio de Janeiro approved a law that led Rio de Janeiro State University (UERJ) and State University of Northern Rio de Janeiro (UENF) to be the first two Brazilian universities to adopt race-based quotas. ${ }^{14}$ In 2003, the University of Brasília also introduced race-based affirmative action, after an intense debate begun in 1999 by a proposal of two anthropology professors (Siqueira 2004; Carvalho 2005; Belchior 2006). Since then, affirmative action policies have been adopted in Brazil's public higher education system. In 2008, on the edge of UFRJ's internal debate on affirmative action, 62 public institutions of higher education used some kind of reservation policy in the admission process. In most cases, having attended high school in a public establishment was employed as a class-based marker. In other situations, race-based selection reserved a place for black, brown and indigenous students. A different combination of criteria has also been employed. For example, 10 universities (including the University of São Paulo and the State University of Campinas) adopted a bonus system that increased the score for selected applicants (Heringer and Ferreira 2009; Paixão et al. 2010; Machado and Silva 2010). In the 2000s, white students that were not admitted in public universities started to file lawsuits to contest the constitutionality of race-based quotas. In April 2012, Brazil's Supreme Court ruled on a case promoted by the right-wing party Democratas (DEM) on the reservation policy adopted by the University of Brasília and decided that quotas in public universities were constitutional. This decision was crucial for the approval, in the same year, of a national law (Bill $\mathrm{n}^{\circ}$ 12.711/2012) establishing that half of the seats in all federal universities have to be reserved for students who attended public high school. Of those spots, half were reserved for low-income students. A share of all reserved seats has also been retained for race-based distribution, according to regional demographic racial composition.

Evaluating the results of the political mobilization started in the 1990s by the black movement with allies in civil society and universities offers differing points of view on these issues. On the one hand, Htun (2004) pointed out the agency of Fernando Henrique Cardoso in advancing a metamorphosis of political action and official discourse on race. According to the author, the President "marked a turning point in the state's approach" and made possible a shift in Brazil's position before the Durban

\footnotetext{
14 The initial system, which reserved $40 \%$ of places to black and brown students, was repeatedly changed. Currently, $20 \%$ of places are reserved for black and indigenous students; $20 \%$ for students who attended high school in the public system; $5 \%$ for people with disabilities and the children of civil and military police officers, military firefighters and prison officers who were killed or disabled in service (Machado 2013).
} 
conference (Htun 2004). A synergic entwining of national and international initiatives created the conditions for a new alignment of forces toward the promotion of affirmative action. On the other hand, Guimarães (2013) stated that this commitment was more formal than substantial. Due to the strong negative reaction of important sectors of Brazilian society against quotas in public universities, until 2007, the Government or the National Assembly had done little to comply with the commitments made in Durban in 2001 (Guimarães 2013). Conversely, before the approval of Law 12.711/2012, affirmative action became effective at the decentralized level through local government or universities. Using interviews with managers and chairs of public universities which adopted affirmative action policies, other scholars offer a different perspective (Paiva 2010; Schwartzman and Silva 2012; Schwartzman and Paiva 2016). According to their research:

Most administrators we talked to see affirmative action as a policy of inclusion and democratization of university access. They often translate an originally racially targeted policy into a socioeconomically targeted policy. Even when the racial component appears, it is mostly not as a cultural identity, but as equivalent to a socioeconomic category (Schwartzman and Silva 2012, 45).

These scholars came to the conclusion that even if the black movement and its allies provided decisive force to trigger the debate on the democratization of Brazil's higher education, it was finally the class-based approach that prevailed in shaping admission and retention policies.

\section{The higher education policy of Lula's administration and the UFRJ}

To understand the drifts of the debate on affirmative action at UFRJ, we first need to introduce the policies that reshaped Brazil's higher education under President Lula (2003-2010). During that period, the Ministry of Education launched several initiatives that expanded the offer of seats - and consequently of funds - in both public and private institutions. But, these measures also challenged university autonomy and forced higher education establishments to rethink their pedagogical foundations as student demographics diversified. Lula's government invested in the private high education system by creating the University for All Program (Programa Universidade para Todos - PROUNI) in 2005 and reformulating the Program of Financing of Higher 
Education Students (Financiamento ao Estudante do Ensino Superior - FIES). ${ }^{15}$ The Plan of Reorganization and Expansion of Federal Universities (Programa de Apoio a Planos de Reestruturação e Expansão das Universidades Federais - REUNI) was created in 2007 to expand higher education in public institutions. It included several mechanisms to increase undergraduate seats, for instance: adding evening courses and financing the opening of new universities and campuses. According to IPEA (2015), the rate of enrollment growth in federal universities was 20\% between 1995 and 1999 and 39\% between 2009 and 2013.

When the REUNI system was adopted, Professor Aloísio Teixeira was the President of UFRJ. Born in 1944, he became a member of the Brazilian Communist Party (Partido Comunista Brasileiro - PCB) in the 1960s when he was studying engineering at university. Persecuted and arrested by the military regime, he obtained a degree in economics in 1978. As Professor at the Institute of Economics of the UFRJ since the 1980s, he held several public positions (Malta 2012). He served two terms as the President of the UFRJ (2003-2011), a role that almost overlapped Lula's presidency. He seriously supported governmental initiatives for higher education. He highly benefited by the ongoing expansion of higher education. In 2003, UFRJ's budget was about USD\$ 11.4 million $^{16}$. Eight years later it was about USD\$ 286.5 million, being USD\$ 107.5 million for infrastructure investments. President Teixeira was also responsible for the pacification of the university after a turbulent period during Prof. José Henrique Vilhena de Paiva's term (1998-2002). ${ }^{17}$ Because President Vilhena lacked credibility and was highly unpopular, his relation with different departments and faculty members at the university was marked by conflict. He consistently undermined the institutional decision-making process. When Professor Teixeira was appointed in 2003, he rebuilt internal dialogue and strengthened academic representative spaces (Alves 2012). Nonetheless, his interaction with the university community was not exempt from friction. Perhaps the bitterest conflict arose from the deliberation about the adhesion to REUNI. This policy, intended to enlarge the number of undergraduate seats in public universities, was challenged by left parties - mainly the Unified Workers' Socialist Party (Partido Socialista dos Trabalhadores Unificado, PSTU) and the Socialism and Liberty Party (Partido Socialismo e Liberdade, PSOL), which

\footnotetext{
${ }^{15}$ The PROUNI allocates scholarships for low-income students that want to attend private universities. The ranking is established using the National High School Exam (Exame Nacional do Ensino Médio - ENEM) score. The FIES provides low-income students with student loans at a lower rate and with a grace period for repayment. The Institute for Applied Economic Research (IPEA 2010, 160) estimated that between 2005 and 2009 about 917 thousand students received PROUNI or FIES support.

${ }^{16}$ Yearly Average Exchange Rate Brazilian Real - US Dollar, 2016.

${ }^{17}$ In 1998, President Vilhena was appointed President of the UFRJ by Brazil's Ministry of Education, even without winning the internal election process. Prof. Teixeira, who received the majority of the votes of faculty, students and staff, opposed President Fernando Henrique Cardoso Government. So, the Ministry of Education intervened and announced the third-placed Vilhena as new president of UFRJ. Despite the legality of the procedure, this prerogative was rarely enforced and was considered a dramatic interference in the internal democratic processes of federal public universities.
} 
opposed Lula's more moderate administration. Under those influences, and similarly to the positions (Léda and Mancebo 2009) adopted by other faculties and students around the country, UFRJ's unions opposed REUNI policies. They considered that the expansion of undergraduate and graduate seats was dissociated from an appropriate increase in budget and faculty hires and that REUNI would eventually worsen work conditions and quality teaching. For the same reasons, foes also complained against the creation of distance learning programs, interdisciplinary courses, and associate degrees (2-year degrees), as foreseen by the REUNI proposal. ${ }^{18}$ In the second half of 2007, the President and the university community debated the issue at length without reaching a consensus. In October 2007, during a session of the University Board, REUNI was approved despite the protests of students and unions. The meeting quickly deteriorated, leading to physical confrontation between supporters and opponents to the policy. The animosity and the distress of the REUNI situation likely led President Teixeira to rethink his strategy for achieving political and institutional approval for implementing further institutional reform.

It is worth noting that at that moment, affirmative action measures were not at play. UFRJ's main forums, like the Board of Undergraduate Courses (Conselho de Ensino de Graduação - CEG) - and the own President, were resistant to the adoption of affirmative action proposals, especially if they were based on racial criteria. When Teixeira was running for a second term as president, in an interview to the newspaper O Globo (Rio de Janeiro), he affirmed that his goal was to expand the number of undergraduate seats, rather than to distribute the existing ones. "Personally, I am not a defender of the quota system because it does not foresee increasing the offer of vacancies, it only distributes the existing ones." ("Sou contra o vestibular', diz Aloísio Teixeira," O Globo, March 13, 2007). In the same interview, he stated that "the Strategic Development Plan foresees more undergraduate places in four or five years. It could double the current number expanding evening undergraduate courses, increasing daytime offerings and creating new courses," ("Sou contra o vestibular', diz Aloísio Teixeira," O Globo, March 13, 2007). This meant he opposed the vestibular system and anticipated a future adhesion to the SISU-ENEM system ${ }^{19}$ ("'Sou contra o vestibular', diz Aloísio Teixeira," O Globo, March 13, 2007). Overall, the statement summarized President Teixeira's understanding of the issue at that time: the problem of access to higher education in Brazil's public universities was a consequence of the shortage of available seats. In his opinion, the expansion of the university system would solve gaps in unequal educational access for poor people and Afro-descendant students. Three

\footnotetext{
18 http://praiavermelha.wikidot.com/blog:adufrj-contra-reuni.

19 The SISU is a national and unified undergraduate admission system based on the candidate performance in the National High School Exam (ENEM), a non-mandatory, standardized national test to assess high school students' learning in Brazil.
}

RASILIANA-Journal for Brazilian Studies. Vol. 6, n.2 (October, 2018). ISSN 2245-4373. 
years later, President Teixeira would be less intransigent in his opposition to a quota system in the undergraduate admissions process. The question is: why?

\section{Resistance and support for affirmative actions at UFRJ}

In the 2000s, UFRJ communities advanced some initiatives for discussing affirmative actions. On August 2003, the Board of Undergraduate Courses (CEG) held a workshop on the democratization of university admission and on the possible use of affirmative action. In June 2004, UFRJ also hosted an event with Vice-Presidents from the State University of Rio de Janeiro, the University of Brasília and the Federal University of Bahia - institutions widely recognized for being the pioneers in the adoption of affirmative action policies in Brazil. In 2006, President Teixeira started a negotiation with the State Government of Rio de Janeiro about a project for an undergraduate selection process, based on serial evaluations for students from public high schools. ${ }^{20}$ In 2006 and 2007, during two national meetings of the Program "Conexões de Saberes" ${ }^{21}$ held at UFRJ, many students questioned the lack of black faculty members and students in the academic community. Provost Laura Tavares reaffirmed the necessity of change to improve diversity, although she did not propose any specific system of affirmative action policy at UFRJ. Overall, these initiatives did not lead to any further proposal, and public support for affirmative action withered until 2010. In the 2000s the resistance against quotas was evident in the UFRJ community. In 2001, President Vilhena, interviewed by Revista Veja, strongly expressed his opposition to the adoption of measures in UFRJ vestibular system ("Entrevista com José Henrique Vilhena de Paiva," Veja, October 17, 2001). The next year, during the IV Congress on Afro-Brazilian Contribution to Historical and Cultural Heritage, the new President of UFRJ, Carlos Lessa, stated: "If social inequality are preserved, which is the value of quotas in the competition process? It is a poison. It is a curse." 22 On May 30, 2006, 113 well-known Brazilian faculty members and scholars signed and published in the press a petition rejecting affirmative action. Almost half (61) of the signatures in the manifesto, entitled "Everybody has equal rights in a democratic Republic" (Todos têm direitos iguais na República Democrática), ${ }^{23}$ were from Rio de Janeiro. UFRJ alone was the university that accounted for the highest number of signatures, seventeen of the total. Their argument

\footnotetext{
${ }^{20}$ O Globo, March 13, 2007

${ }^{21}$ Created in 2004, the Project stimulates a network of universities, the Ministry of Education, poor communities and civil society organizations to discuss policies to foster university admission and permanence in higher education institutions for low-income students. Students of poor communities receive fellowships to support their academic career and participate in research and extension community development.

${ }^{22} \mathrm{https}$ //ufrj.br/noticia/2015/10/22/religafro-come-pregando-igualdade.

${ }^{23} \mathrm{https} / / /$ www1.folha.uol.com.br/folha/educacao/ult305u18773.shtml
} 
was based on the defense of a color-blind egalitarianism and the fear of a racialization of Brazil's society. With the respect to UFRJ's students, in May 2009, a group of them ran for the students' union election (Diretório Central dos Estudantes Mario Prata - DCE) under the name "United for UFRJ - Against QUOTAS" (Unidos pela UFRJ - Contra as COTAS). At the ballot, they came third, obtaining 1,056 votes (14\% of the valid ones). ${ }^{24}$ In a country where aggressive verbalizations of hate are usually hindered, the fact that the denial of quotas was part of the group's name captures more attention than the election results. A possible explanation might be the high socioeconomic status of UFRJ students and their privileged position in Brazilian society and higher educational system. ${ }^{25}$ Another possible factor might be the fear of higher competition and loss of limited seats. One of the faculty unions (Seção Sindical dos Docentes da UFRJ - ADUFRJ) had no official position ("Nota da redação em resposta à carta 'Contra as cotas', ADUFRJ, June 1, 2010), but practically followed left-wing National Faculty Union (Sindicato Nacional dos Docentes das Instituições de Ensino Superior - ANDES) decisions. ${ }^{26}$

Some of the fiercest opposition to UFRJ's affirmative action proposals was offered by the Board of Undergraduate Courses (CEG), because of in-house defensiveness regarding the vestibular system. Adopted in 1988, UFRJ based its admission process on discursive explanations rather than standardized multiplechoice tests ${ }^{27}$, and in the opinion of CEG's members, its system discouraged test-taking tricks and learning methods exclusively based on memorization of questions and answers. CEG claimed that "UFRJ's admission system model strengthens the active participation of the teacher in the classroom and stimulates creativity and citizenship in young people" ("Além do Vestibular", Jornal da UFRJ, Sept 2007, 11). Although the Board of Undergraduate Courses recognized the existence of social disparities, it refused affirmative action policies because considered that inequalities were originated from the poor quality of public schools - and did not arise from UFRJ's meritocratic admission system. As they stated:

CEG is against the adoption of quotas. In a document approved in 2004, CEG assessed that the enrollment in the higher education system is already a democratic process, since it is clear, transparent and nonexclusionary. Representativeness of minorities and students from

\footnotetext{
${ }^{24} \mathrm{http}: / /$ sejarealistapecaoimpossivel.blogspot.com.br/2009/05/eleicoes-do-dce-ufrj-grande-vitoria-da.html.

${ }^{25}$ In $2007,60 \%$ of UFRJ students had attended high school in private institutions and $61 \%$ were white. More than half had a family income superior to five minimum wages and more than $1 / 4$ higher superior to 10 minimum wages (CEG n.d.).

${ }^{26}$ Until 2006 ANDES rejected all forms of affirmative action, advocating for a universal access to higher education. Only in 2010 it revised its opposition to race-based quotas (http://www.andes.org.br/andes/portal.andes).

27 In 1988, President Horácio Macedo decided that UFRJ would adopt a self-organized system for university admission, abandoning the vestibular system organized by CESGRANRIO Foundation, which was used at the time by all the institutions of higher education in Rio de Janeiro State.
} 
public schools is understood as the result of mechanisms and structural factors that affect school trajectory, and not the selection process itself. CEG recognizes the existence of unequal conditions of schooling in Brazil and the fact that those elements are decisive for entering university. However, CEG argues that those conditions are not set by UFRJ's admission exam. ("Além do Vestibular," Jornal da UFRJ, Sept 2007, 11).

Finally, the Board argued that there was no shortage of undergraduate seats in the UFRJ system. On the contrary, in the view of CEG's members, the number of applicants was lower than expected because of school failure among high school students. According to CEG's data, between 1990 and 2010, UFRJ had doubled the number of undergraduate seats (offering about eight thousand new vacancies per year), whereas the number of candidates had not increased, especially when considering public high schools students. Less than $1 / 4$ of the 163 thousand students who had finished high school in 2007 in the Rio de Janeiro State tried to enroll at UFRJ and only $33 \%$ of the applicants had studied in public high schools (CEG n.d.). CEG's Academic Coordinator of the vestibular system claimed:

It exists a perverse system of self-elimination. Many students of the public system are not attracted by the exclusive processes of the most prestigious universities, because they do not consider themselves able to face those selections, or because they do not believe that staying at college for more 4 or 5 years will bring transformations in their future ("Vestibular: perfil de quem tenta," UFRJ Olhar Virtual, Oct. 26, 2007).

Taken together, these results seem to suggest that CEG implicitly considered lowincome, black and brown students responsible for their own exclusion.

Although resistance against affirmative action policy in the UFRJ community was marked during the 2000s, it would be unfair not to recognize faculty members, students and staff members who spoke in favor of this policy. For example, in October 2004, the Institute of Biomedical Sciences approved a document in which supported the implementation of affirmative action policies and the expansion of undergraduate seats. UFRJ has also traditionally hosted important black scholars (for example, writer Joel Rufino dos Santos, geographer Milton Santos, and journalist Muniz Sodré), recognized nationally for their intellectual production, black scholarship and activism against racism and racial discrimination. UFRJ's significance in Brazil's national landscape led several black organizations, like EDUCAFRO and other social movements, to advocate fiercely for the adoption of quotas within the university. In the early 2010s, the quota system for undergraduate admission was an attention- 
grabbing, controversial subject, particularly considering the national debate on the subject. In August 2010, 70 UFRJ faculty members signed the petition "Open Letter on UFRJ's Quotas" (Carta aberta sobre cotas na UFRJ) ${ }^{28}$ in support of the adoption of a reservation policy. A group of faculty and staff mobilized efforts to defend quotas in town halls and mass media. They also created a website ("Cotas na UFRJ") ${ }^{29}$ to share articles and materials in favor of affirmative actions during the internal discussion in that university.

\section{The approval of UFRJ affirmative action policy: checkmate?}

Brazil's Constitution of 1988 stipulates individual university autonomy on issues pertaining to teaching, research, administration, and financial management. ${ }^{30}$ Undergraduate and graduate admission processes are part of the decisions meant to be determined independently by universities. Traditionally, the vestibular systems have been composed of one or more written tests chosen by each university as a method to rank candidates. In 2009, Brazil's Ministry of Education proposed a modification in the college admission process through sponsoring voluntary integration of public and private institutions into a Unified Selection System (Sistema de Seleção Unificada - SISU). The new system aimed to replace the decentralized and independent vestibular processes with a coordinated national system. Theoretically, this change would improve the chances for low-income and geographically remote students to compete for university places in top institutions. In the SISU system, the distribution of seats is not determined by the vestibular result, but by the candidate performance in the National High School Exam (Exame Nacional do Ensino Médio ENEM) - a non-mandatory, standardized national test created in 1998 to assess high school students' achievement in Brazil. ${ }^{31}$ Although participation in SISU was free and voluntary, the vast majority of public universities have been transitioning to this system, ${ }^{32}$ thereby abandoning the traditional vestibular admission process.

\footnotetext{
${ }^{28}$ https://cotasnaufrj.wordpress.com/2010/08/19/carta-aberta-sobre-cotas-na-ufrj/

${ }^{29} \mathrm{https}: / /$ cotasnaufrj.wordpress.com/

${ }^{30}$ However, public universities enjoy just partial autonomy as they cannot decide their annual budget and are subject to public service obligations. Among others, they are subject to federal policies and procedures on faculty and staff compensation, retirement, etc.

${ }^{31}$ In a first phase of SISU, candidates select courses/universities they want to apply for among a pool of public universities all over Brazil. In a second phase, based on the ENEM score, the system automatically selects the topranked candidates in each course/university.

32 In 2016, 11 federal universities and 29 state universities still used their own vestibular system. https:/guiadoestudante.abril.com.br/blog/redacao-para-o-enem-e-vestibular/nao-e-so-pelo-enem-40universidades-publicas-ainda-tem-vestibular-com-redacao/.
} 
During his two terms, President Teixeira expressed his support for reforms and higher education policies adopted by the Federal Government. In 2007, he had already spoken out his opinion about admission exams in public universities: "I am against the vestibular, which does not measure knowledge, it measures income" ("Sou contra o vestibular', diz Aloísio Teixeira," O Globo, March 13, 2007). From its introduction in 2009, UFRJ partially adhered to the new SISU-ENEM system. Yet, as approved by a large majority of the CEG Board, UFRJ's proposal for adopting the SISU-ENEM system showed it would be used only as a first eliminatory stage for ranking candidates.

Perhaps in President Teixeira's mind, that decision was a preliminary step toward the full compliance with the new model. Yet, such an intention would eventually place the President's interests in opposition with the CEG's unrestricted defense of UFRJ vestibular system. By trying to substitute UFRJ's system for the SISUENEM, the President would almost certainly encounter bitter opposition and possibly erode his moral authority, as nearly happened during the REUNI approval in 2007. To avoid the controversy previously generated in the academic community, the President decided to adopt a different strategy in the case of SISU-ENEM. In 2010, Professor Teixeira encouraged a member of the University Councili33 (Conselho Universitário CONSUNI), a researcher on race inequality and publicly-endorsed, race-based policies, to present a proposal for the adoption of affirmative action policies (Paixão 2016). Nevertheless, this move might seem to be in contradiction with Teixeira's position against affirmative action policies, especially race-targeted quotas. As he revealed during the debate on this issue:

I am publicly against quotas, and particularly against racial quotas. The discussion on quotas has the great advantage of showing that we, UFRJ, are a perversely exclusive university. Because of racism. But also, because only a tiny percentage of our students are young people in the appropriate age to attend college. This is a problem that quotas do not answer. The solution is the expansion of the university. The responsibility we have as teachers is to fight for the permanent expansion of the university ("CONSUNI constitui comissão para organizer debates sobre cotas na UFRJ," ADUFRJ, June 1, 2010, 4),

It is true that he also suggested in this article the possibility to reserve places for lowincome students. But, why would the President endorse a public debate on affirmative action policies, considering that the proposal would be submitted by an advocate of

\footnotetext{
${ }^{33}$ The CONSUNI is formed by 37 representatives and it is the collegiate highest body within the University. It has normative, deliberative and planning functions. It is composed of the President (who is the chair of the Council), Vice-President, Provosts, Deans of the university, plus representatives of faculty, staff (total of 3) and students (total of 3).
} 
race-targeted policies? It is reasonable to affirm that in backing a debate on quotas, President Teixeira opted to shift the attention to a highly controversial subject (racial quotas) in order to handle the opposition from the Board of Undergraduate Courses on the SISU-ENEM system. During the entirety of the UFRJ internal examination of affirmative action, CEG did not recognize the legitimacy of the University Council as the most suitable forum to decide on the remodeling of the admission system. In its opinion, that discussion should be conducted by CEG itself. By bringing together the discussion on SISU-ENEM and the controversy surrounding affirmative action, the President increased the scope of the decision and offered a better argument for maintaining the University Council as the decision-making body. Hence, we could conceivably infer that the discussion on affirmative action policies was used by the President as a tool for adopting SISU-ENEM.

Consequently, between 2010 and 2012, the University Council of the Federal University of Rio de Janeiro resumed debating the adoption of an affirmative action policy, which had been only timidly addressed in the early 2000s. The discussion covered three main questions: i) Should UFRJ change its admission system and adopt affirmative action?; ii) What would be the share of places reserved for quotas?; iii) Who would be eligible? On March 11, 2010, a proposal to CONSUNI suggested to institute a reservation policy for black, indigenous people and low-income students. While internal commissions analyzed the petition, the UFRJ community organized town halls to address this question. In general, the audience attending the meetings supported the implementation of affirmative action policies, even if in many cases people expressed concern about the necessity of funds for maintaining low-income students in college (residence halls, university cafeteria and dining halls, fellowships). However, the community could not reach a general consensus. On May 13, the newspaper O Globo depicted UFRJ as a university literally "cracked" by divided opinions by illustrating various student positions ("Cota da discórdia," O Globo, May 13, 2010). In May 2010, the first of three resolutions on affirmative action stated that a commission would be set up to organize public debates. It also established a deadline (August 12) to present new proposals. In the aftermath of the decision, CEG Admission Commission elaborated a report against affirmative actions and the SISU-ENEM system. The position was based on five main arguments: i) university autonomy, insisting that UFRJ should maintain the prerogative to select its own students; ii) criticism of SISU-ENEM model; iii) regionalization, stating that applicants from the best-served regions of Brazil, where the higher-quality schools were concentrated, would end up appropriating the vacancies available all over the country; iv) weakness of ENEM tests and the suspicion of fraud that had occurred in 2009; and finally, v) defense of UFRJ's model and the institutional and academic history of the vestibular system. 
After several meetings organized by the University Council, departments and centers, the CONSUNI adopted Resolution n⿳0 16/2010 in August 2010. This established that $40 \%$ of the undergraduate seats would be determined by the vestibular system and $60 \%$ by the SISU-ENEM system. In the second case, $20 \%$ of the seats would be reserved for students who attended public high schools. In 2011, a new determination, Resolution $\mathrm{n}^{\mathrm{o}}$ 14/2011, integrally adopted the SISU-ENEM system, abandoning the self-organized admission model developed by the CEG. According to this proposal, $30 \%$ of undergraduate seats were now reserved for low-income students ${ }^{34}$ who attended public high schools - without reference to race-based reservations of seats. President Teixeira's strategy finally won. The UFRJ community agreed on the necessity of implementing social quotas - reservation of places for students of lowincome families, whereas the proposal to adopt race-based quotas - defended in the Council meetings by very few scholars, the student body representatives and some of the staff delegates - was repeatedly defeated by the overall majority in the meetings of the University Council.

\section{Final remarks}

In the 2000s, when highly ranked universities were experimenting different mechanisms of inclusion, UFRJ resisted faint attempts to implement admission instruments that could support the access of low-income or black and brown students to higher education. For a long time, UFRJ was considered nationally the headquarters of anti-affirmative action. Several faculty members, mainly social scientists, acted as leaders of the public mobilization against these policies, sponsoring the creation of the petition against quotas in 2006, and publishing in newspapers and academic journals their arguments in opposition to these measures. ${ }^{35}$ President Teixeira himself did not attempt to hide his rejection of affirmative action, but he also did not hesitate to use the political mobilization around this cause to achieve his personal goals. The inflamed debate on affirmative action deflected attention from the discussion on the undergraduate admission mechanism and eventually led SISU-ENEM system to become the sole UFRJ admission process. Yet, the reservation policy only granted 3 out of 10 undergraduate seats for students of public schools and extremely low-income families. One year later, when Brazil's National Assembly passed Law 12.711/2012 (Affirmative Action Law) that determined that federal universities would have 5 years to adopt affirmative action policies, participation in the SISU-ENEM system remained

\footnotetext{
${ }^{34}$ Per capita family income lower than one minimum wage.

${ }^{35}$ To give an idea of the clash among different groups of intellectuals, this debate was referred as a 'culture war' by Bailey and Peria (2010).
} 
optional, but UFRJ had already adopted the system. Moreover, similarly to what occurred in several Brazilian public universities, race-based quotas provided to be the gateway to open debate about affirmative action at UFRJ. Yet, because objections to race-based affirmative action policies remained intense, eventually only class-based criteria were implemented.

Beside identifying the vital role of the President, our analysis of UFRJ's case revealed that the debate on affirmative action was entangled in a national discussion on higher education reforms. This separates our work from the conclusions of other researchers. We have shown how UFRJ's discussion on a reservation policy played into a broader strategy that aimed at approving the SISU-ENEM system over the inhouse application system. Obviously, we recognize the beneficial effect of the SISUENEM system in democratizing access to higher education and improving chances of low-income candidates. Yet, we still argue that at UFRJ, the affirmative action debate was instrumentally used for the implementation of a policy that did not fully address both social and racial discrimination.

Today, even after the approval of the Affirmative Action Law, it is important to investigate the decision-making process on affirmative action in each Brazilian public university. Research can help us to understand fundamental aspects of the true spirit of the quotas, to paraphrase Beraldo and Magrone (2013). In other words, understanding that spirit means not only to unravel what was at stake in the past, but also to foresee possible risks in the consolidation of positive discrimination policies. For instance, would the lack of a substantial reflection on racism, sexism and other forms of prejudice within UFRJ's community during the affirmative action debate affect the quality of these policies in the future?

Toward this end, an example may serve to illustrate our point. On July 2, 2016, a 29-year-old student, Diego Vieira Machado, was found dead on the UFRJ campus evidence of brutal violence was discovered at the scene. He was gay, black, and had received several death threat messages before his tragic fate. At the time of publication, no offender has been discovered. On July 5, 2016, the newspaper O Estado de São Paulo published an article in which several black and brown students denounced hate discourse at UFRJ and revealed that far-right groups were bullying gays, blacks, women, and leftist people. ${ }^{36}$ This is discouraging.

Yet, some positive signs can also be noted, especially as directed by students. UFRJ now counts at least six Afro-Brazilians collectives, pointing to the endeavors made by these students in search for empowerment and self-protection. ${ }^{37}$ As a result

\footnotetext{
${ }^{36}$ Estado de São Paulo, July 5, 2016: "Alunos denunciam grupos com discurso de ódio na UFRJ”. Maria Martín, El País, July 7, 2016: “Assassinato de estudante negro e gay escancara intolerância na Universidade".

${ }^{37}$ Collective of Black Males and Females of Biology Institute; Black Collective of National Law School; Marlene Cunha Black Collective of National Museum; Black Collective Beatriz Nascimento of History Institute; Collective Carolina de Jesus of Institute of Philosophy and Social Sciences; Section of Black Males and Females of Students' Union President (DCE).
} 
of the approval of affirmative action policies, UFRJ's student demographics have changed. In 2007, 64.3\% of the undergraduate students came from private high schools, whereas 7 years later this proportion dropped to 40\% ("Assistência estudantil de qualidade é para ontem", ADUFRJ, May 20, 2014, 6). This also resulted in changes in the beliefs, values, and priorities of the student body.

In the mid-2000s, UFRJ officers were primarily concerned with the task of expanding the infrastructure of their higher education system (REUNI and SISUENEM), thus underestimating the need to be prepared for the symbolic, cultural and political changes that come with increasing diversity within the student body. The future may hold even more changes, as the current Temer Government imposes severe budget constraints and funding cuts for federal universities. For example, between 2014 and 2017, the nominal value of UFRJ budget for expenses and investment fell $3 \% .{ }^{38}$ If the future of the affirmative action policies appeared challenging a decade ago - when the funds were plentiful, today, the situation grows worse. For the latest generation of low-income and Afro-Brazilian undergraduate students arriving at UFRJ, this seems to suggest that their chess game is just beginning. From now on, we hope these students will be the main players.

\section{References}

Alves, Helio de Mattos. 2012. "Aloísio Teixeira: um educador em defesa das causas sociais e democráticas." Revista Princípios, no. 121, 89-95.

Bailey, Stanley R., and Michelle Peria. 2010. "Racial Quotas and the Culture War in Brazilian Academia." Sociology Compass, no. 4: 592-604. doi:10.1111/j.17519020.2010.00295.x.

Bailey, Stanley R., F Fabrício Fialho, and Michelle Peria. 2015. "Support for racetargeted affirmative action in Brazil." Ethnicities. https:/doiorg.ezproxy.lib.utexas.edu/10.1177/1468796814567787.

Belchior, Ernandes Barboza. 2006. "Não deixando a cor passar em branco: o processo de implementação de cotas para estudantes negros na Universidade de Brasília." Master thesis, University of Brasília.

\footnotetext{
${ }^{38} \mathrm{http} / /$ www.portaldatransparencia.gov.br/receitas/consulta.asp?idHierarquiaOrganizacao=154103\&idHierarqui aDetalhe $=0$ \&idDirecao $=0$ \&idHierarquiaOrganizacao0 $=1 \&$ idHierarquiaOrganizacao $1=153939 \&$ idHierarquiaDet alhe $0=0 \&$ Exercicio $=2016$.
}

RASILIANA- Journal for Brazilian Studies. Vol. 6, n.2 (October, 2018). ISSN 2245-4373. 100 
Benedito, Vera Lúcia. 2007. "Uma universidade plural, país de cidadãos: ações afirmativas desafiando paradigmas na Universidade Federal de Mato Grosso do Sul." In Acesso e permanência da população negra no ensino superior, edited by Maria Auxiliadora Lopes and Maria Lúcia de Santana Braga, 113-141. Brasília: UNESCO / BID/ Ministério da Educação.

Beraldo, Antonio Fernando, and Eduardo Magrone. 2013. "Políticas de cotas na Universidade Federal de Juiz de Fora: avaliação 2006-2011." In O impacto das cotas nas universidades brasileiras (2004-2012), edited by Jocélio Teles dos Santos, 105-134. Salvador: CEAO.

Carvalho, José Jorge. 2005. Inclusão étnica e racial no Brasil: a questão das cotas no ensino superior. São Paulo. Attar Editorial.

Cavalleiro, Eliane dos Santos. 2000. Do silêncio do lar ao silêncio escolar: racismo, preconceitos e discriminação na educação infantile. São Paulo: Ed. Contexto.

Comissão de Vestibular do Conselho de Ensino de Graduação da UFRJ - CEG. n.d. Powerpoint presentation named 'Acesso aos cursos de graduação da UFRJ: em discussão.' Rio de Janeiro: UFRJ.

Fry, Peter, Yvonne Maggie, Marcos Chor Maio, et al., ed. 2007. Divisões perigosas: políticas raciais no Brasil contemporâneo. Rio de Janeiro: Civilização Brasileira.

Gaspar, Lúcia, and Virgínia Barbosa. 2013. Ações afirmativas e políticas de cotas no Brasil: uma bibliografia (1999-2012). Recife: Fundação Joaquim Nabuco / Ministério da Educação.

Gomes, Nilma Lino, and Aracy Alves Martins, ed. 2004. Afirmando direitos: acesso e permanência de jovens negros na universidade. Belo Horizonte: Autêntica.

Guimarães, Antonio Sérgio A. 2013. “Brasil, 1996-2012: anotações para uma sociologia política da adoção de cotas no ensino superior público." Paper presented at the XXXI International Congress of the Latin American Studies Association, Washington, DC, May $\quad 30 \quad-\quad$ June 1. http://www.fflch.usp.br/sociologia/asag/Notas\%20para\%20uma\%20sociologia\%20pol itica $\% 20$ da $\% 20$ adocao $\% 20$ de $\% 20$ cotas $\% 20$ no $\% 20$ ensino $\% 20$ superior.pdf.

Hasenbalg, Carlos, and Nelson do Valle Silva. 1990. “Raça e oportunidades educacionais no Brasil." Cadernos de Pesquisa, nº 73, 5-12. 
Henriques, Ricardo, ed. 2000. Desigualdade e pobreza no Brasil. Rio de Janeiro: IPEA.

Heringer, Rosana. 2001. "Mapeamento de ações e discursos de combate às desigualdades raciais no Brasil." Estudos Afro-Asiáticos 23 (2): 1-43.

Heringer, Rosana, and Renato Ferreira. 2009. "Análise das principais políticas de inclusão de estudantes negros no ensino superior no Brasil no período 2001-2008." In Caminhos convergentes: Estado e sociedade na superação das desigualdades raciais, edited by Marilene Paula and Rosana Heringer, 137-194. Rio de Janeiro: Fundação Heinrich Boll / Action Aid.

Hordge-Freeman, Elizabeth. 2015. The color of love: racial features, stigma, and socialization in black Brazilian families. Austin, TX: University of Texas Press.

Htun, Mala. 2004. "From 'racial democracy' to affirmative action: Changing state policy on race in Brazil." Latin American Research Review 39 (1): 60-89.

Instituto Brasileiro de Geografia e Estatística - IBGE. 2016. Estatísticas do Cadastro Central de Empresas. Rio de Janeiro: IBGE.

Instituto de Pesquisa Econômica Aplicada - IPEA. 2010. Políticas sociais: acompanhamento e análise $n^{\circ} 19$. Brasília: IPEA.

2015. Políticas sociais: acompanhamento e análise n² 23. Brasília: IPEA.

Kent, Michael, and Peter Wade. 2015. "Genetics against race: Science, politics and affirmative action in Brazil." Social Studies of Science 45 (6): 816-838.

Léda, Denise Bessa, and Deise Mancebo. 2009. "REUNI: heteronomia e precarização da universidade e do trabalho docente." Educação $\mathcal{E}$ Realidade 34 (1): 49-64.

Lopes, Maria Auxiliadora, and Maria Lúcia de Santana Braga, ed. 2007. Acesso e permanência da população negra no ensino superior. Brasília: UNESCO / BID/ Ministério da Educação.

Machado, Elielma Ayres. 2013. Ação afirmativa, reserva de vagas e cotas na Universidade do Estado do Rio de Janeiro (2002-2012). Rio de Janeiro: FLACSO. 
Machado, Elielma Ayres, and Fernando Pinheiro da Silva. 2010. "Ações afirmativas nas universidades públicas: o que dizem os editais e manuais." In Entre fatos e dados: ação afirmativa nas universidades públicas brasileiras, edited by Angela Randolpho Paiva, 19-50. Rio de Janeiro: PUC-RJ and Pallas Ed.

Malta, Maria Mello de. 2012. “Lutador imprescindível." Desafios do desenvolvimento 9 (73).

http://www.ipea.gov.br/desafios/index.php?option=com_content\&view=article\&id=2 794: catid=28\&Itemid=23.

Marteleto, Letícia J., and Molly Dondero. 2016. "Racial inequality in education in Brazil: A twins fixed-effects approach." Demography 53, n. 4 (August): 1185-1205.

Moraes, André Guerra Esteves, and Walter Belluzzo. 2014. "O diferencial de desempenho escolar entre escolas públicas e privadas no Brasil." Nova Economia 24, n. 2 (Maio-Agosto): 409-430.

Paiva, Angela Randolpho, ed. 2010. Entre fatos e dados: ação afirmativa nas universidades públicas brasileiras. Rio de Janeiro: PUC-RJ and Pallas Ed.

Paixão, Marcelo. 2009. The paradox of the "good" student: race and the Brazilian education system. Washington, DC: PREAL.

2016. “Memórias de uma luta memorável.” Jornal da ADUFRJ, 15 (1): 14-19.

Paixão, Marcelo, and Luiz M. Carvano, ed. 2008. Relatório anual das desigualdades raciais no Brasil; 2007-2008. Rio de Janeiro: Garamond.

Paixão, Marcelo, Irene Rossetto, Fabiana Montovanele, and Luiz M. Carvano, ed. 2010. Relatório anual das desigualdades raciais no Brasil; 2009-2010. Rio de Janeiro: Garamond. Santos, Jocélio Teles dos, ed. 2012. Cotas nas universidades: análises dos processos de decisão. Salvador: CEAO.

ed. 2013. O impacto das cotas nas universidades brasileiras (2004-2012). Salvador:

CEAO.

Santos, Renato Emerson, and Fátima Lobato, ed. 2003. Ações afirmativas: políticas públicas contra as desigualdades raciais. Rio de Janeiro: DP\&A.

$\mathrm{R}^{\text {RASILIANA- Journal for Brazilian Studies. Vol. 6, n.2 (October, 2018). ISSN 2245-4373. }}$ 
Schwartzman, Luisa Farah, and Graziela Moraes Silva. 2012. "Unexpected narratives from multicultural policies: translations of affirmative Action in Brazil." Latin American and Caribbean Ethnic Studies 7(1): 31-48.

Schwartzman, Luisa Farah, and Angela Randolpho Paiva. 2016. "Not just racial quotas: Affirmative action in Brazilian higher education 10 years later." British Journal of Sociology of Education 37 (4): 548-566.

Siqueira, Carlos Henrique Romão de. 2004. "O processo de implementação das ações afirmativas na Universidade de Brasília(1999-2004)." O público e o privado, no. 3 (JanJun): 165-188.

Telles, Edward E. 2004. Race in another America: The significance of skin color in Brazil. Princeton: Princeton University Press.

Viáfara López, Carlos Augusto, and Nini Johanna Serna Alvarado. 2015. “Desigualdad de oportunidades educativas en la población de 15 a 29 años en Brasil y Colombia según autoclasificación étnico-racial." Sociedad y Economia, no. 29 (June): 151-174.

Wade, Peter. 2017. Degrees of mixture, degrees of freedom: genomics, multiculturalism, and race in Latin America. Durham and London: Duke University Press. 